\title{
VALUE EDUCATION AND WOMEN'S \\ EMPOWERMENT: \\ A COMPELLING PRIORITY OF CHRISTIAN EDUCATIONAL INSTITUTIONS IN INDIA
}

\author{
MOLLY K. ABRAHAM \\ Jesus and Mary College \\ Chanakyapuri, New Delhi -110021 \\ E-mail: mll.abraham@gmail.com
}

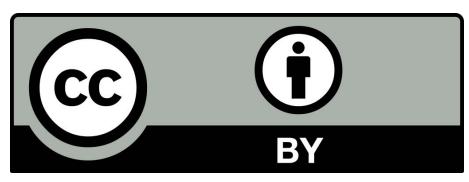

If you invest in a girl or woman you're investing in everyone else

- Melinda Gates

\begin{abstract}
Today all development agencies in India agree on the importance of value education and the need to empower women in order to promote and maintain family, health, nutrition and general well-being of the people in the society. Education for women should always be directed towards their holistic development. The vision behind the Christian leadership in women's education left an indelible mark on the lives of many generations throughout the world. Institutions of Christian education for girls have left a tradition of providing both basic education and professional education for a century and a half. This paper looks into the extent of Christian educational institutions in the process of assimilation of values and their contribution to women for the building up of a democratic India in terms of their leadership, commitment to the family and nation, and dedication to the general welfare of the people.
\end{abstract}

Key words: Value, Education, Women, Empowerment, Christian

\section{INTRODUCTION}

"Go ye therefore, and teach all nations" (Matt. 28:19, Revised Standard Version) - is the universal mission of the Christian Church, commissioned by Jesus. But education in India, being regarded from a short range point of view, results in expediency, mass mania of materialism and spiritual bankruptcy. The impressive economic growth rate contributed to the reduction of illiteracy, mortality rates and poverty. The Gross domestic product (GDP) growth in the January-March quarter of 2010-11 went up from 7.3\% to $9.2 \%$ (India's GDP Growth slumps to 6.5 percent in 2011-12, 2012). It caused the improvement of living standards and life expectancy. But the challenges are still alarming. 
Education for all still remains an elusive dream in India. As per the survey in 2011 , the literacy gap between men and women in India is $22 \%$ points whereas the world average gap is $18 \%$. The overall literacy rate in India is $74.04 \%$ in the year 2011. The male literacy was $82.14 \%$ and female literacy rate was a mere $65.46 \%$. Among the states, Kerala had the highest female literacy rate with $94.00 \%$ and Bihar, the lowest with a mere 33.57\% (Indian Census Bureau, 2011). The much celebrated advantages of globalization had its own setbacks in terms of exclusionary politics, materialistic goals and skewed educational policies. It had no commitment to organization and society, and wanted rapid benefit and immediate recognition. The values of this generation of youth reflected in an extremely competitive situation where each person does what is the best for himself/herself alone. In spite of various efforts on the part of the government and other agencies to equalize opportunities, gender disparity prevails in the Indian society. Since education instills in women a sense of confidence to face challenges, women's literacy is essential for economic vitality and independence. Education increases women's awareness about their rights and potentials. The value education, therefore, becomes a compelling priority in the agenda of any Christian institution in a country like India.

Investing in women's capabilities and empowering them to exercise their choices is not only valuable in itself but also the surest way to contribute to the economic growth and overall development. Education Institutions train young women in such a way that they apply their acquired knowledge to the pursuits of daily life and make them fit for the position they have to occupy. Education for women should always be directed towards their holistic development. India has 1.2 billion people with 20 million Christians having 20000 colleges and 400 universities. It has two Catholic and four Christian universities. As of now, there are over 350 Christian managed colleges and more than 250 among them are catholic colleges spread across the country with higher concentration in the south of India (Thadathil, 2011, p. 6). In such a context, Christian educational institutions in India have a major role to play in empowering women through their education.

\section{CHRISTIAN EDUCATION WITH A VISION}

The Indian Education Commission, an ad hoc commission set up by Indian Government to examine all aspects of the educational sector in India, observes that the greatness of a country does not depend on the extent of its territory, the length of its communication or the amount of its wealth, but on the love for higher values of life. All must develop thought for the poor and suffering, regard and respect for women, faith in brotherhood regardless of race, colour, religion etc. (Kothari, 1966, p. 32). As we focus on the role of Christian educational institutions in empowering women through their education, it should address more specific questions such as what were the most important contributions that the Christian educational institutions have given to 
women's empowerment in the society and in what ways the education and teaching-learning process in the institutions are proving helpful to women. We should also look into the extent to which these institutions contributed to the empowerment of women in terms of their contributions to their family and the society.

The Indian Education Commission insists that the educational institutions should become centers of excellence which promote equality and social justice, and to reduce social and cultural differences through diffusion of knowledge. They should foster in the teachers and students and through them in society generally the attitudes and values needed for developing a good life (Kothari, 1966, p.14). The vision of Christian educational institutions is based on the same humanistic vision of man and society. These institutions promote their students with education which instils in them deep spiritual, moral and social values. They prepare young women who are capable of doing hard, sustained work for society. They teach how to adopt a balanced view of life, and to develop a sense of dedication, duty and respect for others. In the Christian educational institutions the students learn the basic lessons of love and sense of justice toward one's neighbour. The purpose of true education is certainly to promote the quality of the life of man, and in consequence, the quality of the life of society itself. The National Council Of Educatioal Research and Training, an autonomous organization of the government of India, envisions education as "a process of inculcating values among children" (Gupta, \& Baveja, 2014, p. 27). Therefore, to educate means to bring up, so as to form habits, manners, intellectual aptitudes, discipline, taste and positive disposition in life. It is the content of one's character and personality which determines ultimately one's success or failure in life.

\section{VALUE BASED EDUCATION: THE NEED OF THE HOUR}

The education system in India is yet to declare a world of values well nursed by the children of one world, one society and one big brotherhood of mankind. This common language for mutual understanding is the lesson most needed to be inculcated in our parochial system of education. The values are norms laid down by society for desirable behaviour which help human beings to live a healthy, peaceful and productive life (Chakrabarti, 1997, p. 12). What is desirable today may not be desirable tomorrow and what is desirable here may not be desirable elsewhere; values are related to the time and place, and are thus subjective and relative. Menuhin-Hauser, the renowned American pianist writes, "We are living between two eras, between rich and poor, between the old and the young, and we are also caught between the macro-symptoms and the micro-symptoms of imminent social and personal breakdown. In this ambivalent situation we are not quite sure of knowing the right way" (1974). The repressed sense of ambivalence leads to a desperate kind of frustration that drives people mad, and creates in their blocked minds a readiness to put 
the blame on others. Ambivalence which expresses itself, on the other hand, leads to democracy of the mind away from extremes, away from obsessions and away from fanatical partisanship. A value based educational system makes one examine other people's ways of life and other people's view-points (Chakrabarti, 1997, p. 27).

\section{FAITH AND HUMAN VALUES}

In the encyclical letter Laudato Si 'Praised Be', Pope Francis expressed his firm belief in the right to choose a "moral and faith-based education" for young people. He pointed out that in today's ever-changing, technological world, youngsters are bombarded with so much information that it is difficult to filter through it. Therefore, the young people should be guided to critical thinking and a moral compass (Francis, 2015). That is exactly where a faith-based education comes in. The young women in Christian institutions are made increasingly aware of their gift of faith in themselves and in God. These institutions introduce young women to the human values and lead them to an active participation in worship in their respective realm of belief. The end result is that each one realizes that one is created by God according to His "image and likeness" (Gen. 1:26). This vision aims to impart education to young girls in tune with their social position. This has been the founding mission of the Christian educational institutions. They visualised the formation of a young generation which is comprised of good social beings infused with a sense of duty towards the society of which they are a part. It has been observed that when educationists neglect the significance of character formation in education, we subsequently become a nation without character (Chakrabarti, 1997, p. 29). The very people of a nation should form and build its own character, and then that becomes the life source of a nation. For a nation to live in continual progress, it is important that its people are well educated. According to Swami Vivekananda, "Education means that process by which character is formed, strength of mind is increased, and intellect is sharpened, as a result of which one can stand on one's own feet" (Barman, \& Bhattacharyya, 2012, p. 31).

Through value education and by setting good examples, we impart knowledge other than what is just given in the text books. In this age of scientific knowledge with its commitment to technological advancement, there is no room for superstition and blind faith. The logical and reason-based actions are acceptable in the present age of knowledge explosion and knowledge-driven society. So the development of scientific temper and scientific attitudes are now considered to be a prime objective of formal education. Christian educational institutions combined two ideals, namely, good life based on human values and the means to earn a decent livelihood. They help women to become good citizens, leaders, mothers, wives and teachers, within their families and in the society as well. 


\section{CHALLENGES IN VALUE EDUCATION AND WOMEN'S EMPOWERMENT}

In India today, the pressures of the prevailing caste system, communalism, poverty and other exploitative structures make it imperative to equip young women not only with intellectual skills, but also with a set of strong attitudes imbued with spiritual, moral and social values. The society gives women a subordinate status, and due to that they may miss opportunities and have become victims of deprivation, discrimination and atrocities. The role of education in understanding and appreciating the self in relation to others and the divine self encapsulates the essence of values. This enables us to be in perfect tune with the truth. The Christian educational institutions are committed to this kind of education in order to teach young girls to reach out to the poor and the least favoured. Their education also seeks to make them conscious about their rights in the struggles they face in the midst of all oppression, social evil and exploitation in the materialistic and consumerist society of today. They invite their collaborators, students, parents as well as benefactors to work for the realisation of this objective in forming a nation without any social disparities.

Awareness of oneself, knowledge of one's strengths and limitations, respect for other human beings irrespective of their race, colour, creed and culture, sensitivity to the feelings of all living things in the environment, an altruistic attitude, a sense of honesty and humility are the basic qualities that are ingrained in a person through quality education (Kothari, 1966, p. 45). The Christian educational institutions aim to instruct young girls in the importance of such values. For Christian institutions, education is the means which enabled the students to attain the ultimate success in life. Imbued with the Spirit of Christ, the students would act as "Leaven and Salt" (Matt. 5:13) in their own social milieu.

\section{THE VISION FOR A NEW WORLD ORDER}

To establish a new world order of compassion, peace, justice and security, it is essential that mankind free itself from the limitations of national prejudice and acknowledge that the forces that unite it are incomparably more powerful than those that divide it. The spirit of Christian educational institutions promotes the concept that all people are part of the one global community, dependent on one body of resources, bound together by the spirit of oneness. This Christian vision affirms that the resources of the globe are finite, not infinite; that they are the heritage of no one nation or generation, but of all peoples and for posterity. Education helps women to resist exploitation, besides, of course, empowering them to be self reliant. Women's literacy is essential for economic vitality and independence (Braun, Chudowsky, \& Koenig, 2001, p. 41).

Education increases women's awareness about their rights and capabilities. An educated and independent woman takes decisions concerning various aspects of her life. Women are allowed to participate as equal partners in the process of national development only when equal opportunities to women in all 
areas of life are provided. Empowerment implies greater access to knowledge and resources, greater ability to plan one's life, greater control over circumstances that influences one's life and overcome the restrictions and constraints imposed by customs, beliefs and practices. Women's empowerment can be attained only through meeting their needs and interests. Education thus is a pathway and has been recognised as a major instrument which societies can use to direct the process of change and development towards desired goals. It also affirms that the exploitation of the poor by the rich and of the weak by the strong violates our common humanity and denies life, liberty, and happiness to the large segments of society. These Christian educational institutions recognise a moral obligation to strive for a more prudent and more equitable sharing of the resources of the earth in order to ameliorate poverty, hunger and disease (Flannery, 1998, p. 78).

\section{THE SIGNIFICANCE OF WOMEN'S EDUCATION IN INDIA}

The Indian Education Commission stresses the need for education to be related to the life and needs of the people here and now (Kothari, 1966, p. 29). Even long before this Education Commission was appointed, the Christian educational leadership believed in training the young women under their care to become mature individuals in the society. They were taught to work which would make them self supporting and independent human beings. It is true that the destiny of a nation is shaped in the classroom. The classrooms of our schools have girl children usually from the age of four till the university level in some cases. The Christian educational visionaries seemed to have foreseen the UNESCO's dictum even before its origin: "If we educate a boy, we educate a man, and if we educate a girl, we educate a family, and in consequence, a nation" (Pal, 1993, p. 7). Education is one of the powerful instruments to effect change and development in society. Education is one of the powerful instruments to effect change and development in society.

As women are responsible for fostering well being in families, education for women throughout their lives is essential to increase global prosperity and integration. In classrooms, we have children at the most formative stage of their lives. It is there that we either make or mar the future citizens of India. Therefore, it is indispensable that we educators draw the best out of each child, and lay the foundations of the uniqueness of each individual created in God's own likeness and image. The educational level of women is particularly important because educational attainment can affect the age of marriage, reproductive behaviour, the health and nutritional levels of the family, proper hygienic practices and above all, their own status.

Female education has been found to have a more significant effect on lowering the poverty line and promotion of sustainable development, influencing family size and female labourers. In tune with this concept, His Holiness Pope Pius XI said “The supreme importance of Christian education, not merely for each individual but for families and for the whole human society, whose 
perfection comes from the perfection of elements that composed it" (Gibbon, 1939, p. 79). The Christian educational institutions have been the pioneers in the field of women's education in India. Through their education they have been forming outstanding citizens in all walks of life throughout the country. They have produced many distinguished intellectuals, professionals, administrators, political and national leaders like doctors, lawyers, teachers, members of the administrative service, government officers, army personnel and entrepreneurs in industry and business (Abraham, 2008, p. 267). There is no considerable amount of research in terms of excellence based on a ranking of Christian educational institutions in comparison with non- Christian or government educational institutions. But it has been observed that Christian educational institutions achieve stronger educational outcomes in areas like completion rates, academic results, success at the tertiary level and promoting social cohesion. They have formed men and women of integrity, self discipline and moral calibre who have become shining examples and inspiration in public life (Chakrabarti, 1997, p. 51).

\section{CONCLUSION}

The present system of Christian education in India, in whatever shape and condition it is, has to accept the challenge and strive towards the unity and integration of the people, and their moral, spiritual growth. Unless Christian education institutions take up the challenge of educating women and fulfilling their mission to this objective of goodness to the larger humanity, it fails to prepare good citizens. Life becomes purposeful and progresses only when it lets itself be guided and governed by these values. With the pluralistic set up of a country like India, Christian educational institutions should further equip women with the skills of critical thinking and discernment.

The role of the Christian educational institutions in bringing about a positive change in the society through women's education is undoubtedly great. In fact, parents and guardians strongly believe that children become value-conscious either as individuals or as social representatives through their education at Christian educational institutions. The following prominent women who left the portals of Christian educational institutions after the completion of their studies tell their success stories: Ms. Sheila Dixit, Chief Minister of Delhi; Ms. Shailaja Kumari, Dy. Minister of Education; Priyanka Gandhi, Politician; Mrs. Ritu Marwah, Dy. Director of Education, Delhi; Aruna Roy, Indian political and social activist served as an officer in the Indian Administrative Service from 1968-1975; Mrs. Sangeeta Singh, MP; Lok Sabha, Aung San Suu Kyi, Nobel Laureate and socialist in Myanmar, fighting for civil rights. These people and many like them have brought both name and fame to the nation through their achievements (Abraham, 2008, p. 267). At the same time, the Christian educational institutions have been criticised for the role they have played in developing an elitist mentality and fundamentalistic in their attitude wherever they have been operating. 


\section{REFERENCES}

1. Abraham, M. (2008). Contribution of the Congregation of Jesus and Mary towards the Female Education in North India (1840-1950) (Doctoral dissertation). Retrieved from the University Library, Agra.

2. Barman, P., \& Bhattacharyya, D. (2012). Vivekananda's Thoughts on Man-making through Moral Values and Character Development and its Present Relevancy in School Education. International Journal of Multi-disciplinary Educational Research, 2. 30-37.

3. Braun, H., Chudowsky, N., \& Koenig, J. (Eds.). (2001). Getting Value Out of Value - Added. Washington, DC: The National Academies Press.

4. Chakrabarti, M. (1997). Value Education: Changing Perspectives. New Delhi: Kanishka.

5. Flannery, A. (1998). Documents of Vatican II. Bombay: St. Paul Publications.

6. Gibbons, S. J., \& William J. (1939). Seven Great Encyclicals. New York: Paulist Press.

7. Gupta, N. K., \& Baveja B. (2014). Basics in Education. New Delhi: NCERT Publication.

8. Indian Census Bureau. (2011). Literacy in India. New Delhi: Government Press. Retrieved from http:/ / www.census2011.co.in/literacy.php.

9. India's GDP Growth slumps to 6.5 percent in 2011-12. (2012, May 31). India today. Retrieved from http://indiatoday.intoday.in/story/gdp-growth-sharply-down-at-6.5-per-cent-in-2011-12/1/198325.html.

10. Kothari, D. S.(1966). The Indian Education Commission Report. New Delhi: Govt. of India Publication.

11. Menuhin-Hauser, C. (1974). A Common language for Mutual Understanding Culture. UNESCO, 3( 4), 150-151.

12. Pal, G. (1993). Women's Education for a Better Nation. Documentation on Women's Concerns, 3, 5-7.

13. Francis. (2015, May 24). Encyclical Letter. Laudato Si. Retrieved from http://w2.vatican.va/ content/francesco/en/encyclicals/documents/papa-francesco_20150524_enciclica-laudato-si.html.

14. Thadathil, G. (2011). The Role of Catholic Institute od Higher Education in Democratizing People. Edición de contenidos- Universidad Católica de Ávila, 26-29. 